\title{
The Determinants of Youth Integration in the Romanian Labour Market
}

\author{
Maria Denisa Vasilescu and Amalia Cristescu \\ National Scientific Research Institute for Labour and Social Protection, and the Bucharest University of \\ Economic Studies, Bucharest, Romania
}

Correspondence should be addressed to: Maria Denisa Vasilescu; mariadenisa.vasilescu@gmail.com

Received date: 2 September 2017; Accepted date: 22 August 2017; published date: 28 December 2017

Academic Editor: Ana-Maria Neagu

Copyright (C 2017. Maria Denisa Vasilescu and Amalia Cristescu . Distributed under Creative Commons CC-BY 4.0

\begin{abstract}
The social inclusion of young people has been a major issue in recent times. Employment is essential for social integration - with a quality job young people are stimulated to increase their economic potential, to develop their knowledge and skills, and to contribute to the socioeconomic development of the country. The integration of young people into employment is an essential issue with a strong economic and social impact. This paper aims at analysing the youth labour market in Romania compared to the EU, and to identify the factors (personal and environmental characteristics) that determine the youth status in the labour market: employed versus unemployed, part-time versus full-time and freelancer versus employed.
\end{abstract}

Keywords: youth employment, labour market, logistic regression, Romania

\section{Introduction}

Young people are the ones who can significantly influence the direction that the workforce in Europe will follow in the next years. The European Union supports the professional development of young people and believes in their power to generate change and contribute to the smart, sustainable growth, favourable to the inclusion that the Europe 2020 Strategy proposes. Young people hold the key to the prosperity and dynamism of the European Union. Their skills, energy and creativity will help the European Union to develop and become more competitive, as it will overcome the economic and financial crisis.

Cite this Article as: Maria Denisa Vasilescu and Amalia Cristescu (2017)," The Determinants of Youth Integration in the Romanian Labour Market ", Journal of Eastern Europe Research in Business and Economics, Vol. 2017(2017), Article ID 356502, DOI: 10.5171/2017.356502 
Nevertheless, young people have been particularly affected by the crisis.

Currently, the youth unemployment rate in the European Union is higher than $20 \%$ twice more than the unemployment rate associated with all age groups together and almost 3 times higher than those over the age of 25 . Also, in the European Union, nearly 6 million people under the age of 25 do not have a job and about 7.5 million do not have a profession and are not enrolled in any educational or training programme (Eurostat, 2015). These young people are both a huge unexploited resource, that the European Union cannot afford to waste, and a social problem that the European Union must end. Unemployment among young people has a powerful impact on individuals but also on society and the economy. If current trends are not reversed quickly, the present levels of youth unemployment are likely to damage the young people employment prospects in the longer term, with serious implications for the economic growth and for the future social cohesion.

In the larger framework of the European strategy for economic growth and creating jobs, the premise of helping young people to enter and remain on the labour market and to acquire and develop the skills that will enable them to apply for a job is, therefore, an absolute priority for any European Union Member State. Throughout the economic crisis, the European Commission has worked with the Member States to combat the economic and social consequences of the continuously growing high unemployment rate. The effects of some of these efforts will only be seen in time (European Commission, 2015).

Youth unemployment is a highly debated issue among economists and researchers, and literature on the subject is vast (Blannchflower and Freeman, 2007; Bell and Blanchflower 2011a,b; Caliendo et al, 2011; O'Higgins, 2001 and 2015). Two approaches have been distinguished, depending on the point of view from which the situation of young people on the labour market was analysed: a macroeconomic and a microeconomic perspective.

From the macroeconomic point of view, the main causes of youth unemployment are the aggregate demand, the size of the youth workforce, the youth wages, as well as labour market specific institutional factors, such as the minimum wage or employment protection legislation. The factors that influence youth unemployment are generally the same that influence unemployment in general. But there are also a number of specific elements that influence the number of young unemployed people. Thus, we can identify the lack of qualification, young people with no practical experience or those who obtained qualifications with no demand on the labour market are difficult to employ. Most companies want to invest as little as possible in the primary training of a new employee, especially in times of economic crisis. Another factor is the economic cyclicality. At present, many young people are unemployed because of the economic crisis. Firms prefer, because of the lack of money, to hire people with experience if they really need to increase their workforce. The geographical, cultural and social influences also have an important role in increasing the number of young unemployed people. Usually, some areas/regions of a country (regions subject to economic restructuring, isolated regions, small regions with low employment opportunities, etc.) are more affected than others. Also, the underground economy is an important factor, as it can lead to a distortion of the official number of unemployed people in areas where the black labour market is well developed (Alexandru, 2014).

The microeconomic approach is focusing on personal characteristics that influence young people's participation in the labour market. The variables most often used to explain the success of young people in finding a job are gender, age, residency, and education. In general, very young people, young men and young people living in rural areas are less 
likely to find a job (Marks and Fleming, 1998).

Regarding the link between age and youth success in the labour market, there is an inverse correlation between unemployment rate and the young individuals' age (Wooden, 1996; Borland, 1997), the explanation for this being simple and intuitive: as a person gets older, she/he becomes more qualified and more experienced, thus increasing the chances of employment. In a more recent study, Escudero and Mourelo (2013) found that age is an important factor influencing the youth labour market status: young people aged 15 to 24 years have a $22.4 \%$ greater chance of being in inactivity than adults (individuals over 35 years old). This difference is not explained by the fact that young people are still studying, this factor being controlled in the research.

The most recent ILO report, World Employment and Social Outlook 2016, Trends for Youth, shows important disparities between young men and women, the labour market participation rate being $53.9 \%$ for young men, and only $37.3 \%$ for young women in 2016. In the European Union, young men are more likely to be unemployed: in 2015 the unemployment rate for young men was $21.1 \%$ and $19.5 \%$ for young women.

The residence area also influences youth employment. The big cities offer more opportunities on the labour market while many rural areas are facing a decline in employment. Chapman and Smith (1992) concluded that in rural areas the average unemployment time for a young individual was 56 weeks compared to only 24 weeks for young people living in urban areas. Cartmel and Furlong (2000) state that youth unemployment in rural areas may be higher because rural youth face a narrower range of opportunities, and a more limited access to education and training.

Education is one of the most important drivers of individual success in the labour market, both in terms of employment as well as wages. For young people with higher levels of education it is easier to find a job because employers believe that they can adapt more easily to the job requirements and the cost of specific training is smaller. Vocational training and higher education significantly increases the chances of a young person to find work (Escudero and Mourelo, 2013).

However, Carmeci and Mauro (2003) argue that knowledge gained in formal education is not sufficient to ensure success in the labour market because employers believe that this knowledge is not directly applicable to the workplace and does not guarantee the productivity and efficiency of a young individual. In these circumstances, any experience young people acquire outside formal education, such as volunteering activities or internships in companies, organizations, or NGOs, is highly valued by employers.

Another aspect that was investigated by researchers in connection to youth integration on the labour market is family background. Recent studies have focused on the relationship between youth unemployment and their family situation. The main conclusion was that the family members' occupation and status influence the employability of young individuals, because the family can create a professional network through their colleagues and acquaintances (Verhaeghe et al, 2012, Zhang and Zhao, 2011).

Also, the way youth extend their social network matters a lot for getting a job. The increased use of the Internet in recent years is noticed especially among young people. There is a positive impact of the internet on youth labour market success by increasing the level of knowledge (the Internet is used in the learning process), by connecting the youth with the economic and political environment (young people read news mostly online) and by expanding social and professional networks (Joorabchi et al, 
2013).

\section{The Current Situation of Young Europeans on the Labour Market}

The unemployment rate among young Europeans has increased in the years following the economic crisis, reflecting the difficulties that the young people face in finding a job, especially young people with low skill levels. However, this does not necessarily mean that the group of unemployed people with ages between 15 and 24 is as large as the group of people older than 25. Most young people are enrolled in the education process and therefore are neither employed nor looking for a job (thus they are not part of the workforce which is used as the denominator in calculating the unemployment rate).

In the EU-28, the highest unemployment rates among young people under the age of 25 are found in Greece (49.8\%), Spain (48.3\%), Croatia (43\%) and Italy (40.3\%). Basically, in these states about 4 in 10 young people do not have a job. In Romania, the youth unemployment rate is close to the European average (21.7\%).

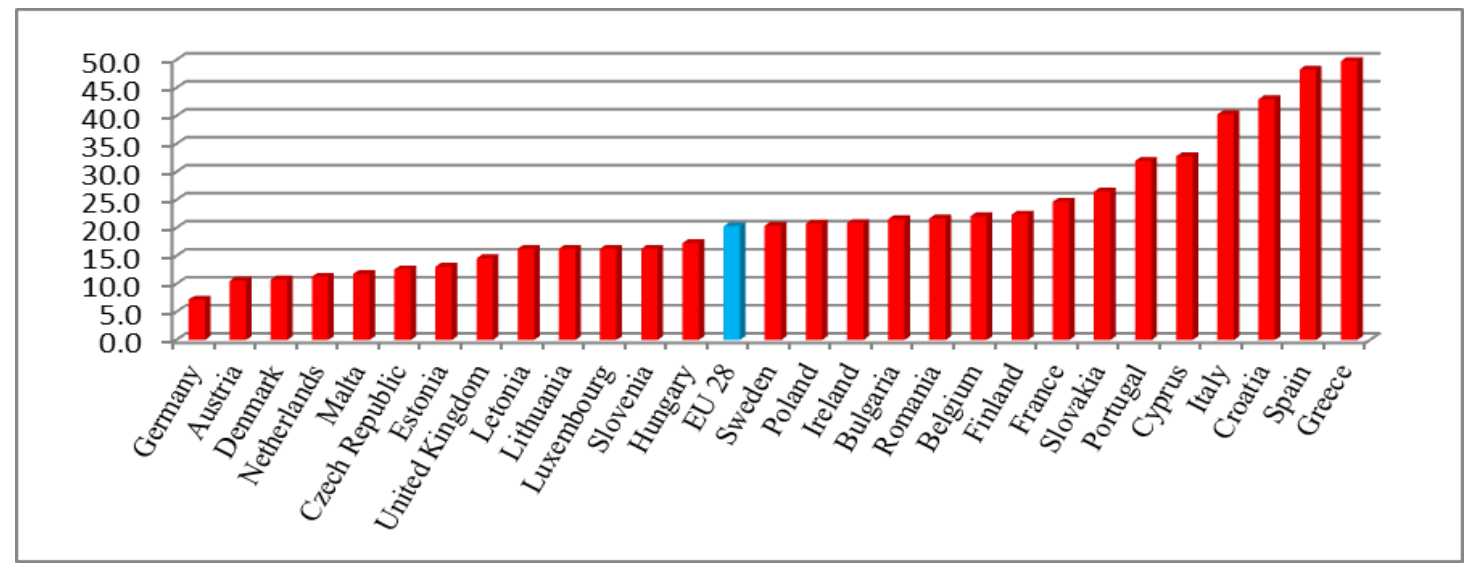

Data source: Eurostat

Fig. 1: Unemployment rate among young people under 25 in EU countries - 2015

Long-term unemployment is a major concern for policy makers. Besides its financial and social effects on personal life, long-term unemployment negatively affects social cohesion and, ultimately, it may hinder the economic growth. In EU-28 the percentage of young people who are long-term unemployed has increased steadily after the financial and economic crisis. Long-term unemployment has varied considerably between the Member States of the EU. In 2015, Greece registered the highest unemployment rates in the long term, as $28 \%$ of the active young people with ages between 15 and 24 were in this situation. Higher rates of long-term unemployment for the 15-29 age group were also recorded in Italy (22\%) and Croatia (20.2\%). At the other end of the top, the lowest long-term unemployment rates were registered among young people in Austria, Finland, Sweden, Denmark and Germany with values below $2 \%$. In Romania, the percentage of long-term unemployed young people was $8.1 \%$ in 2015 , with 1.6 percentage points above the European Union average.

The level of education is an important differentiating factor when assessing the extent of unemployment rates. In all EU countries, except Romania, it seems that the higher the level of education, the lower the unemployment rate. Regarding the EU 28, 
the unemployment rate among people with primary or no education (ISCED $0-2$ ) is $28 \%$, the unemployment rate of young people with secondary education (ISCED 3-4) is $18.2 \%$ and the unemployment rate among higher education youth (ISCED 5-8) is $15.4 \%$ (see Figure 2). It can be noted that in Slovakia, Spain and Greece, the unemployment rate among people with poor or no education exceeds $50 \%$. In Romania, the situation is slightly atypical compared to the European trend in terms of youth unemployment by level of education. One explanation could be that many of the uneducated or low educated people do not declare themselves unemployed, and most of the time they work on the black market as seasonal or day labourers.

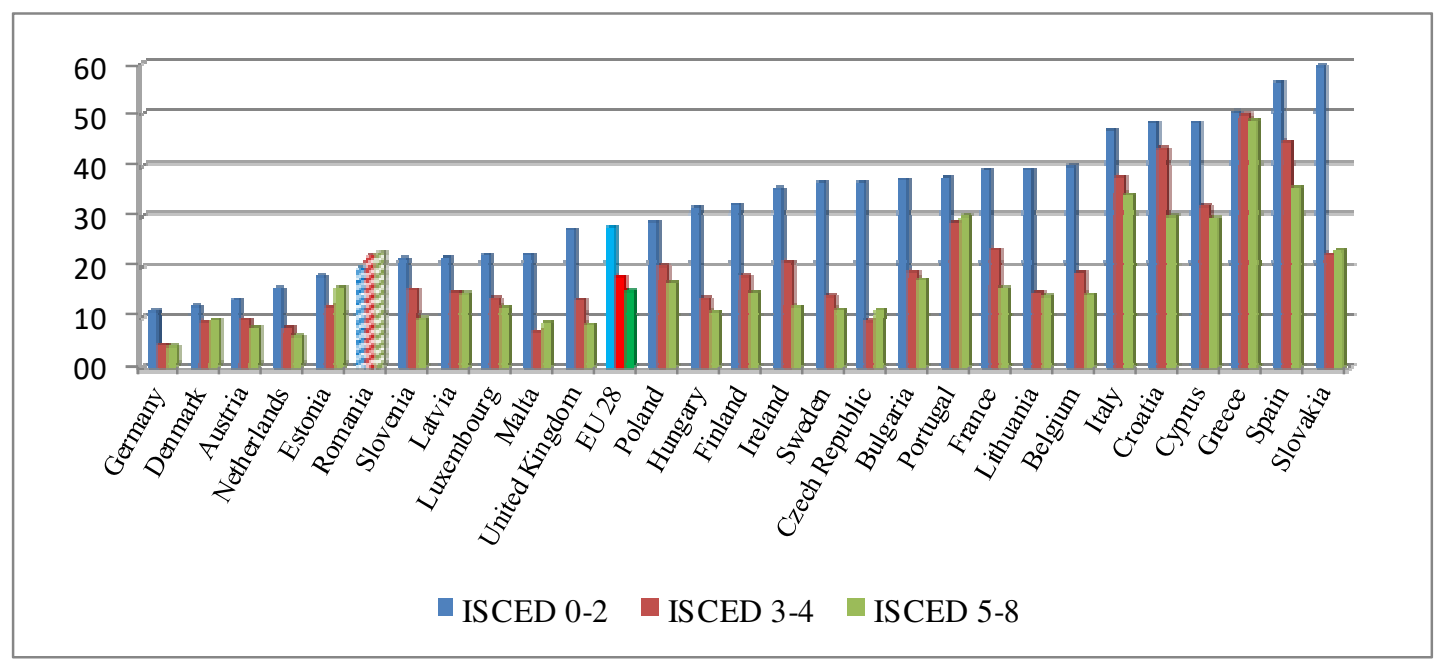

Data source: Eurostat

\section{Fig. 2: Unemployment rate in relation to the level of education among young people under} 25 in EU countries - 2015

For many young people, part-time employment contracts are a good way to combine education and employment, but they can also be influenced by family or other personal reasons. Part-time contracts are most popular among the 15-24 age group. At the EU level, the part-time employment rate among people with ages between 15 and 24 was $32.2 \%$ in 2015 . The highest rates of parttime employment were registered in the Netherlands (80\%) and Denmark (67\%) and the lowest in Bulgaria (5.7\%) and Hungary (6.9). In Romania, the percentage of parttime employed young people was 19.2\%, which is 13 percentage points lower than the European average (see Figure 3).
The predominance of part-time employment contracts is significantly different between men and women. In 2015, the share of young women who worked part-time (40.6\%) was almost twice higher than the share of men (24.9\%) in the EU-28. The biggest difference between men and women was observed in Sweden (24 pp) and Slovenia (22 pp). Romania is the only EU country where the share of part-time employed young men $(19.7 \%)$ was higher than that of women $(18.4 \%)$. The differences between women and men with regard to part-time employment could be linked to the fact that women devote more time to family responsibilities. 


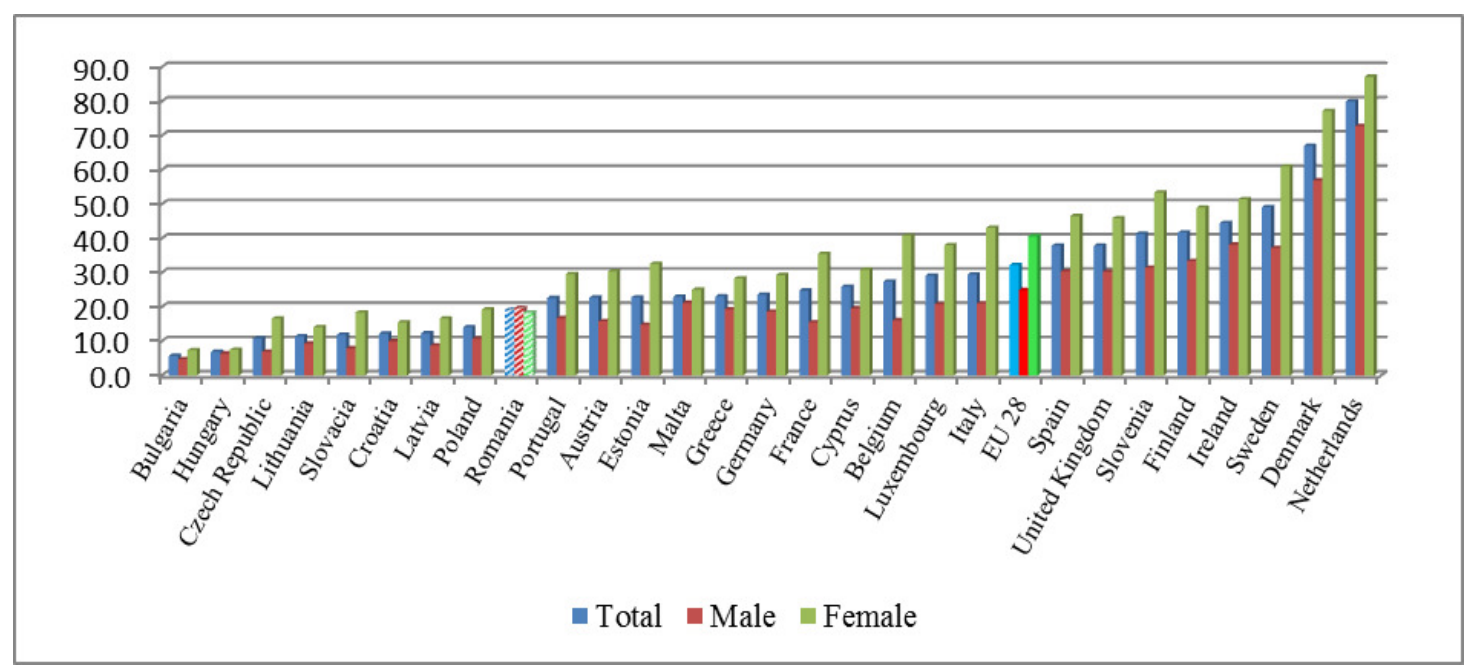

\section{Data source: Eurostat}

Fig. 3: The share of young part-time employees under 25 in EU countries - 2015

Regarding the reasons that have led young people to get part-time jobs, we notice that at the EU level, the main reason is, somehow obvious, the fact that young people are enrolled in the education or training process (56.9\%). Another reason is the impossibility of finding a full-time job (28.1\%), especially since young people face problems on the labour market because of the lack of experience, insufficient training etc. (see Figure 4). In Romania the situation is slightly different from that of the EU. The main reason why most young Romanians work part-time $(74 \%)$ is the impossibility of finding a job. A percentage of $10.3 \%$ said that there are other reasons why they were employed part-time, only $8 \%$ mentioned education or training, and $6.2 \%$ said they were taking care of children and adults in the family and this did not allow them to have a full time job.

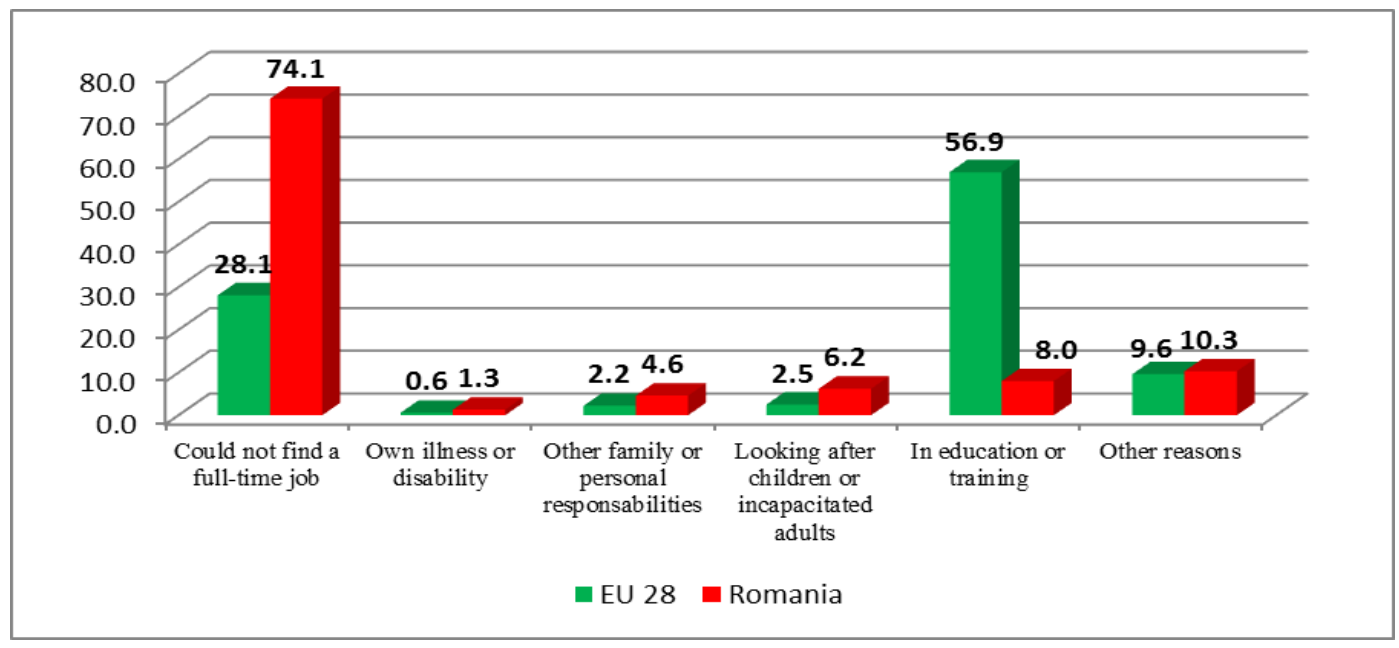

Data source: Eurostat

Fig. 4: Reasons for young people to work part-time - 2015 


\section{Data and Methodology}

The data used in the econometric analysis come from a survey of Romanian youth (Sandu et al, 2016), covering topics like employment; education; leisure, tourism and sport; social conditions; religion and values; political behaviour, attitudes and opinion; family life and marriage; concerns and aspirations; demographic information. The survey was addressed to Romanian young people, aged 15 to 29 years, in July 2014. The selection method consisted in a probability sample - multistage sample, the data being collected through face-to-face interviews by Center for Urban and Regional Sociology, Bucharest. The entire dataset contains 1302 units, with 257 variables.

In order to analyse the differences between employed and unemployed youth, we constructed a binary variable (employment), taking the following values: 1 - if the young respondent is either employed (full-time or part-time) or freelancer and 0 - if the respondent declared to be unemployed. Under these circumstances, our database contains 580 individuals, out of which $15.7 \%$ are unemployed.

The explanatory variables describe the youth's profile: socio-demographic indicators (age, gender, residence), human capital (level of education, Internet use), family background (parents' characteristics), social networks (volunteering activity). Age is a categorical variable taking 3 possible values: 1 if the respondent is 15 to 19 years old, 2 if the interviewed person's age is in the 20-24 years interval and 3 for young adults, aged 25 to 29 years. Gender is a classical binary variable: 1 for males and 0 for females. Residence indicates if the young respondent lives in an urban area (value 1) or in a rural area (value 0). We also considered the historical regions: Moldova (1), Muntenia (2), Transilvania (3) and Bucharest (4). In order to quantify the level of education, we constructed a categorical variable based on the highest educational qualification of the respondent: 1 - stands for ISCED 0-2 (primary education or lower secondary education), 2 - represents ISCED 3-4 (upper secondary education or post-secondary non tertiary education) and 3 - indicates ISCED 58 (short-cycle tertiary education, bachelor level, master or doctoral studies). As the Internet became an important part of youth's life, we investigated its influence on the individual's participation on the labour market. The variable included in the study (Internet use) refers to the amount of time young people spend online daily: more than 6 hours (1), between 2 and 6 hours (2), or less than 2 hours daily (3). We also considered the volunteering activity of young respondents: a binary variable that takes the value 1 if the interviewed person was engaged in voluntary work in the past 12 months and the value 0 otherwise. Since this analysis is targeting young people, it is important to illustrate their family characteristics. For this, we used the parents' social class, as defined by the respondent, with 4 possible values: upper class (1), middle class (2), working class (3) and lower class (4).

The analysis is continued by investigating the characteristics of young people who work part time versus full time, respectively freelancers compared to those employed. The same explanatory variables described above are taken into account.

Given the nature of our variables and the purpose of the study, we used a logistic regression model as econometric method. The logistic regression is used when the dependent variable is binary, taking only two values $(0 / 1), 1$ indicating the realization of an event. The logit model is: 


$$
\pi(y=1 \mid x)=\frac{e^{x+\beta x}}{1+\varepsilon^{x+\beta x}} \quad \text { or } \quad \ln \left(\frac{\pi(y=1 \mid x)}{1-\pi(y=1 \mid x)}\right)=\alpha+\beta x
$$

with $\frac{\pi(y=1 \mid x)}{1-\pi(y=1 \mid x)}=\theta$, commonly known as odds ratio. The model becomes $\ln \theta=\alpha+\beta x$ (Freedman, 2009).

When there are $k$ explanatory variables, the logit model can be written:

$$
\ln \theta=\beta_{0}+\beta_{1} x_{1}+\beta_{2} x_{2}+\cdots+\beta_{k} x_{k}
$$

The multiplicative form of the logit model facilitates the interpretation:

$$
\theta=\exp \left(\beta_{0}\right) \cdot \exp \left(\beta_{1} x_{1}\right) \cdot \exp \left(\beta_{2} x_{2}\right) \cdot \ldots \cdot \exp \left(\beta_{k} x_{k}\right)
$$

If $\beta_{i}=0$ then the corresponding factor $\left(x_{i}\right)$ has no effect, if $\beta_{i}>0$ then the factor increases the probability of the event to occur and if $\beta_{i}<0$, the corresponding factor reduces this probability.

\section{Econometric Results}

The aim of this analysis was to identify the most important personal and environmental factors that contribute to the employability of young people in Romania. We performed several logistic regressions using SPSS software, choosing the command for multinomial regression in order to easily interpret the categorical explanatory variables.

\section{a. Employed versus unemployed}

First of all, we wanted to see what makes a young person more prone to be employed. The results indicated that age is an important factor in explaining young people's success in finding a job than being unemployed (see table 1). It can be seen that with age increases the probability of being employed. Young people aged between 20 and 24 years are 2.8 times more likely to be unemployed than young adults (25-29 years). Teenagers are the most vulnerable group, their chance of being unemployed is three times higher compared with young people aged 25 to 29 years. In general, a younger person has a lower level of specific knowledge and experience in the labour market so the chances of finding work are smaller.
In our analysis, gender and area of residence were not statistically significant indicating that the differences between young men and women, and rural versus urban youth are not very high in terms of unemployment.

As expected, young people's level of education is very important in the Romanian labour market, the econometric results indicating a positive correlation between education and employability of young people. Compared to young university or postuniversity graduates (ISCED 5-8), for those who have completed high school or postsecondary non tertiary education (ISCED 34) the chances to be unemployed are twice higher. The situation is even worse for young people with primary or lower secondary education (ISCED 0-2), as the probability of being unemployed is 3.3 times higher than for those with tertiary education. These results are consistent with the literature and with the youth situation in most EU countries. Thus, given that the official data from Eurostat reports for Romania an unemployment rate surprisingly smaller for young people with lower educational level, these results are an indication that these young people often do not declare themselves unemployed, usually working in the informal economy. 
Regarding Internet use, young people who stay online for more than 2 hours a day are more likely to be unemployed. This occupation increases the chances of unemployment by 1.65 times for those who spend between 2 and 6 hours a day on the Internet and by 1.74 times for those staying online over 6 hours daily, compared to young people who use the Internet less than 2 hours a day. An interesting aspect is this little difference between the two groups (2 to 6 hours a day versus more than 6 hours): it seems that in terms of success in the labour market, an optimal duration of Internet use would be under 2 hours a day. One explanation for these results is that young people who use the Internet very much become addicted to it, thereby decreasing their interest in other activities, including work.
Another interesting aspect of this study is that young people who have not participated in volunteering activities in the past 12 months are 4.2 times more likely to be unemployed compared to those who were involved in such activities. Two aspects can explain this result. On one hand, the volunteer work resembles to a paid job in many ways, therefore young individuals learn teamwork, learn to meet deadlines, to be organized and punctual, they develop communication skills, and they learn how to develop relationships with clients, colleagues and superiors. These skills cannot be learned in formal education and are highly valued by employers. On the other hand, volunteering involves extending social and professional network and can often be the source of a job recommendation.

Table 1: The logistic regression estimation results - employed versus unemployed Parameter Estimates

\begin{tabular}{|c|c|c|c|c|c|c|c|c|c|c|}
\hline & \multirow{2}{*}{\multicolumn{2}{|c|}{ Employment $^{a}$}} & \multirow{2}{*}{ B } & \multirow{2}{*}{ Std. Error } & \multirow{2}{*}{ Wald } & \multirow{2}{*}{ df } & \multirow{2}{*}{ Sig. } & \multirow{2}{*}{$\operatorname{Exp}(B)$} & \multicolumn{2}{|c|}{$\begin{array}{l}95 \% \text { Confidence } \\
\text { Interval for } \operatorname{Exp}(B)\end{array}$} \\
\hline & & & & & & & & & $\begin{array}{l}\text { Lower } \\
\text { Bound }\end{array}$ & $\begin{array}{l}\text { Upper } \\
\text { Bound }\end{array}$ \\
\hline \multirow{6}{*}{ Unemployed } & Intercept & Intercept & $-3,597$ & ,673 & 28,607 & 1 &, 000 & & & \\
\hline & Age & $\begin{array}{l}15-19 \\
20-24 \\
25-29\end{array}$ & $\begin{array}{r}1,143 \\
1,057 \\
0^{b}\end{array}$ & $\begin{array}{l}, 452 \\
, 280\end{array}$ & $\begin{array}{r}6,404 \\
14,248\end{array}$ & $\begin{array}{l}1 \\
1 \\
0\end{array}$ & $\begin{array}{l}, 011 \\
, 000\end{array}$ & $\begin{array}{l}3,137 \\
2,879\end{array}$ & $\begin{array}{l}1,294 \\
1,662\end{array}$ & $\begin{array}{l}7,606 \\
4,985\end{array}$ \\
\hline & Volunteering & $\begin{array}{l}\text { No } \\
\text { Yes }\end{array}$ & $\begin{array}{r}1,434 \\
0^{b}\end{array}$ & 489 & 8,605 & $\begin{array}{l}1 \\
0\end{array}$ &, 003 & 4,194 & 1,609 & 10,932 \\
\hline & Internet use & $\begin{array}{l}\text { more than } 6 \text { hours } \\
2 \text { to } 6 \text { hours } \\
\text { less than } 2 \text { hours }\end{array}$ & $\begin{array}{r}, 554 \\
, 502 \\
0^{b}\end{array}$ & $\begin{array}{l}, 371 \\
, 278\end{array}$ & $\begin{array}{l}2,225 \\
3,255\end{array}$ & $\begin{array}{l}1 \\
1 \\
0\end{array}$ & $\begin{array}{l}, 136 \\
, 071\end{array}$ & $\begin{array}{l}1,740 \\
1,652\end{array}$ & $\begin{array}{l}, 840 \\
, 958\end{array}$ & $\begin{array}{l}3,601 \\
2,849\end{array}$ \\
\hline & Education & $\begin{array}{l}\text { ISCED 0-2 } \\
\text { ISCED 3-4 } \\
\text { ISCED 5-8 }\end{array}$ & $\begin{array}{r}1,180 \\
, 685 \\
0^{b}\end{array}$ & $\begin{array}{l}, 490 \\
, 346\end{array}$ & $\begin{array}{l}5,789 \\
3,924\end{array}$ & $\begin{array}{l}1 \\
1 \\
0\end{array}$ & $\begin{array}{l}, 016 \\
, 048\end{array}$ & $\begin{array}{l}3,253 \\
1,984\end{array}$ & $\begin{array}{l}1,244 \\
1,007\end{array}$ & $\begin{array}{l}8,503 \\
3,909\end{array}$ \\
\hline & $\begin{array}{l}\text { Parents' social } \\
\text { class }\end{array}$ & $\begin{array}{l}\text { Upper class } \\
\text { Middle class } \\
\text { Working class } \\
\text { Lower class }\end{array}$ & $\begin{array}{r}-1,490 \\
-1,019 \\
-, 974 \\
0^{b}\end{array}$ & $\begin{array}{l}, 829 \\
, 392 \\
, 378\end{array}$ & $\begin{array}{l}3,227 \\
6,751 \\
6,628\end{array}$ & $\begin{array}{l}1 \\
1 \\
1 \\
0\end{array}$ & $\begin{array}{l}, 072 \\
, 009 \\
, 010\end{array}$ & $\begin{array}{l}, 225 \\
, 361 \\
, 378\end{array}$ & $\begin{array}{l}, 044 \\
, 167 \\
, 180\end{array}$ & $\begin{array}{r}1,145 \\
, 779 \\
, 793\end{array}$ \\
\hline
\end{tabular}

a. The reference category is: Employee or freelancer

b. This parameter is set to zero because it is redundant.

The social class of the respondent's parents has proved important for the employability of a young individual. Compared with young people whose families are in the lower class, all others are less likely to be unemployed. Again, there may be several explanations for these results. Poorer families do not always 
have the financial possibilities to support the young in completing their studies to a higher level. Moreover, even parents sometimes

have difficulties in the labour market: they are unemployed, are working in the informal economy or as day labourers. The higher chances of being employed obtained for young people in mid and high social classes is due to the fact that their parents can help them find work through colleagues and acquaintances, therefore creating a social network for the young individuals. Also the parents can financially support them until finding a job that suits their qualification, thus reducing the risk of fluctuations between periods of unemployment and employment.

\section{b. Part-Time Versus Full-Time Employment}

Young people are often considered to be part of vulnerable groups on the labour market because they find it hard to find a job. The difficulty of finding a job is caused by several factors, among which the most important are the lack of experience and the level of education. In these conditions, part-time jobs seem to be a viable alternative for young people because they allow them to continue their studies in parallel and in time to gain experience in different fields of activity. The econometric results indicated that part-time jobs are more numerous among young people aged 15-19, this age segment having 5.5 times more chances of having a part-time job compared to the age segment of 25-29 years. Even the 20-24 age group has 2.2 times more chances of having a part-time job compared to the 25-29 age group (see table 2 ). These results are normal given that most of the time young people under 24 are still in school and basically by choosing a part-time job they try to combine education, by continuing their studies, with their professional life, by taking a job. Sometimes a part-time job is for young people also a way to fund their studies and have financial independence.
Corresponding to age, we also have the level of education, so we can see that young people with primary education (ISCED 0-2) have 8.8 more chances to have a part-time job compared to young people with tertiary education (ISCED 5-8). The possibility of having a part-time job decreases with the increase in education so that young people with secondary education (ISCED 3-4) have only 3.1 more chances to have a part-time job compared to those with tertiary education. In Romania there are programs through which employers are encouraged to hire young people part-time, even during school holidays, by providing financial incentives. During the economic recession in recent years, part-time jobs were a solution to avoid sending employees to unemployment, practiced by companies not only for young people but also for the rest of their employees.

We also notice that the use of the Internet influences the ability to get a part-time job. Thus, young people who spend more than 6 hours a day on the Internet do not have time for a part-time job, since the Internet occupies practically all their time. In contrast, those who moderately use the internet (between 2 and 6 hours) have 1.9 times more chances to work part-time than those who use the Internet less than 2 hours a day. Thus, a moderate use of the Internet allows young people to engage in part-time jobs, but also to be informed and to continue their studies.

Young people involved in volunteering are more likely to work part-time than those who are not involved in such activities. This can also be justified by the fact that young volunteers, through the projects they are involved in, get in touch faster with the employers' area and, implicitly, with the labour market.

Regarding the origin region of the young part-time employees we observe that, compared to Bucharest-Ilfov region, in all the other three historical regions, young people are more likely to be employed part-time. Young people in Moldova have 5.5 times 
more chances to become part-time employees, in Muntenia 2.8, and those in Transylvania 1.9 times more chances than young people in the capital / metropolitan region. An explanation for this phenomenon might be that part-time employment of young people is also determined by the financial situation of the family, thus young people often choose to work so that they can earn a living for themselves but also for the rest of the family. We notice that the chances of having a part-time job evolve in reverse proportion to the income level of the analysed regions. Part-time employment is often not a voluntary choice of young people to gain experience on the labour market, but it is a situation imposed by the low level of income of their families. Part-time employment can also be the only chance for these young people to continue their studies.

Table 2: The logistic regression estimation results - part time versus full time

\begin{tabular}{|c|c|c|c|c|c|c|c|c|c|c|}
\hline \multicolumn{11}{|c|}{ Parameter Estimates } \\
\hline \multirow{2}{*}{\multicolumn{3}{|c|}{ part_time" }} & \multirow{3}{*}{\begin{tabular}{|l|} 
\\
$-3,856$ \\
\end{tabular}} & \multirow{3}{*}{$\begin{array}{r}\text { Std. Error } \\
.663 \\
\end{array}$} & \multirow{3}{*}{$\begin{array}{l}\text { Wald } \\
33,815 \\
\end{array}$} & \multirow{3}{*}{\begin{tabular}{l|} 
df \\
1 \\
\end{tabular}} & \multirow{3}{*}{\begin{tabular}{l|} 
Sig. \\
.000 \\
\end{tabular}} & \multirow{3}{*}{$\operatorname{Exp}(B)$} & \multicolumn{2}{|c|}{$\begin{array}{l}95 \% \text { Confidence } \\
\text { Interval for } \operatorname{Exp}(\mathrm{B}) \\
\end{array}$} \\
\hline & & & & & & & & & Lower & Upper \\
\hline \multirow{6}{*}{ Part time } & \multicolumn{2}{|l|}{ Intercept } & & & & & & & & \\
\hline & Age & $\begin{array}{l}15-19 \\
20-24 \\
25-29\end{array}$ & $\begin{array}{r}1,710 \\
.832 \\
0= \\
\end{array}$ & $\begin{array}{r}.491 \\
.285 \\
.\end{array}$ & $\begin{array}{r}12,110 \\
8,517 \\
\end{array}$ & $\begin{array}{l}1 \\
1 \\
0\end{array}$ & $\begin{array}{l}.001 \\
.004\end{array}$ & $\begin{array}{l}5,529 \\
2,298\end{array}$ & $\begin{array}{l}2,111 \\
1,314\end{array}$ & $\begin{array}{r}14,486 \\
4,019\end{array}$ \\
\hline & Education & $\begin{array}{l}\text { ISCED 0-2 } \\
\text { ISCED 3-4 } \\
\text { ISCED 5-8 }\end{array}$ & $\begin{array}{r}2,182 \\
1,247 \\
0= \\
\end{array}$ & $\begin{array}{l}.521 \\
.374\end{array}$ & $\begin{array}{l}17.543 \\
11.126\end{array}$ & $\begin{array}{l}1 \\
1 \\
0 \\
\end{array}$ & $\begin{array}{l}.000 \\
.001\end{array}$ & $\begin{array}{l}8,868 \\
3,481\end{array}$ & $\begin{array}{l}3,194 \\
1,673\end{array}$ & $\begin{array}{r}24,622 \\
7,245\end{array}$ \\
\hline & Region & $\begin{array}{l}\text { Moldova } \\
\text { Muntenis } \\
\text { Transilvania } \\
\text { Bucharest }\end{array}$ & $\begin{array}{r}1.708 \\
1.036 \\
.688 \\
0=\end{array}$ & $\begin{array}{l}.546 \\
.536 \\
.538\end{array}$ & $\begin{array}{l}9,771 \\
3,741 \\
1,635\end{array}$ & $\begin{array}{l}1 \\
1 \\
1 \\
0\end{array}$ & $\begin{array}{l}.002 \\
.053 \\
.201\end{array}$ & $\begin{array}{l}5.517 \\
2,819 \\
1,989\end{array}$ & $\begin{array}{r}1.891 \\
.986 \\
.693\end{array}$ & $\begin{array}{r}16,098 \\
8,059 \\
5,707\end{array}$ \\
\hline & Volunteering & \begin{tabular}{|l|} 
No \\
Yes \\
\end{tabular} & $\begin{array}{r}-.626 \\
0^{5} \\
\end{array}$ & .307 & 4,150 & $\begin{array}{l}1 \\
0 \\
\end{array}$ & .042 & .535 & .293 & .977 \\
\hline & Internetuse & $\begin{array}{l}\text { More than } 6 \text { hours } \\
2 \text { to } 6 \text { hours } \\
\text { Less than } 2 \text { hours }\end{array}$ & $\begin{array}{r}-.090 \\
.660 \\
0= \\
\end{array}$ & $\begin{array}{l}.487 \\
.287\end{array}$ & $\begin{array}{r}.034 \\
5.285\end{array}$ & $\begin{array}{l}1 \\
1 \\
0\end{array}$ & $\begin{array}{l}.853 \\
.022\end{array}$ & $\begin{array}{r}.914 \\
1.935\end{array}$ & $\begin{array}{r}.352 \\
1.102\end{array}$ & $\begin{array}{l}2,372 \\
3,396\end{array}$ \\
\hline
\end{tabular}

\section{c. Freelancer Versus Employed}

Another way for young people to integrate into the labour market is to be freelancers and to carry out their own activities that give them the opportunity to continue their studies as well as some financial independence. Analysing the econometric results (table 3), we can see that young volunteers have more chances to carry out freelancing activities than those who are not involved in such actions.
The Internet use influences the practice of freelance activities among young people, thus those who spend between 2 and 6 hours on the Internet have 2.9 times more chances of being freelancers than those who use the Internet for less than 2 hours. It is possible that the use of the Internet itself is part of the independent activities that young people carry out. Using the Internet for more than 6 hours per day no longer allows young people to have freelance activities too. 
Depending on the historical region of origin of young people, we notice that young people in Transylvania have a spirit of doing more entrepreneurial activities than young people in Bucharest-Ilfov capital region. Young people in Transylvania have 4.6 times more chances to be freelancers than those in the capital region, young people in Moldova have 2 times more chances, while those in Muntenia have fewer chances to be freelancers than those from Bucharest. This situation could also be determined by the fact that several counties in Transylvania (Cluj, Brasov, Sibiu, etc.) promote the encouragement of young people to carry out freelancing activities. At the same time,
Transylvania is a renowned region for the promotion of clusters and networking.

Considering the type of family from which young people come, we can see that young people coming from middle-class and working class families are most likely to carry out freelancing activities (2.8 times more likely compared to young people from families with low incomes). Young people coming from high income families do not seem to be very interested in becoming freelancers, and this is probably also determined by the fact that the family can support them financially and they do not have to have other professional activities.

Table 3: The logistic regression estimation results - freelancer versus employed

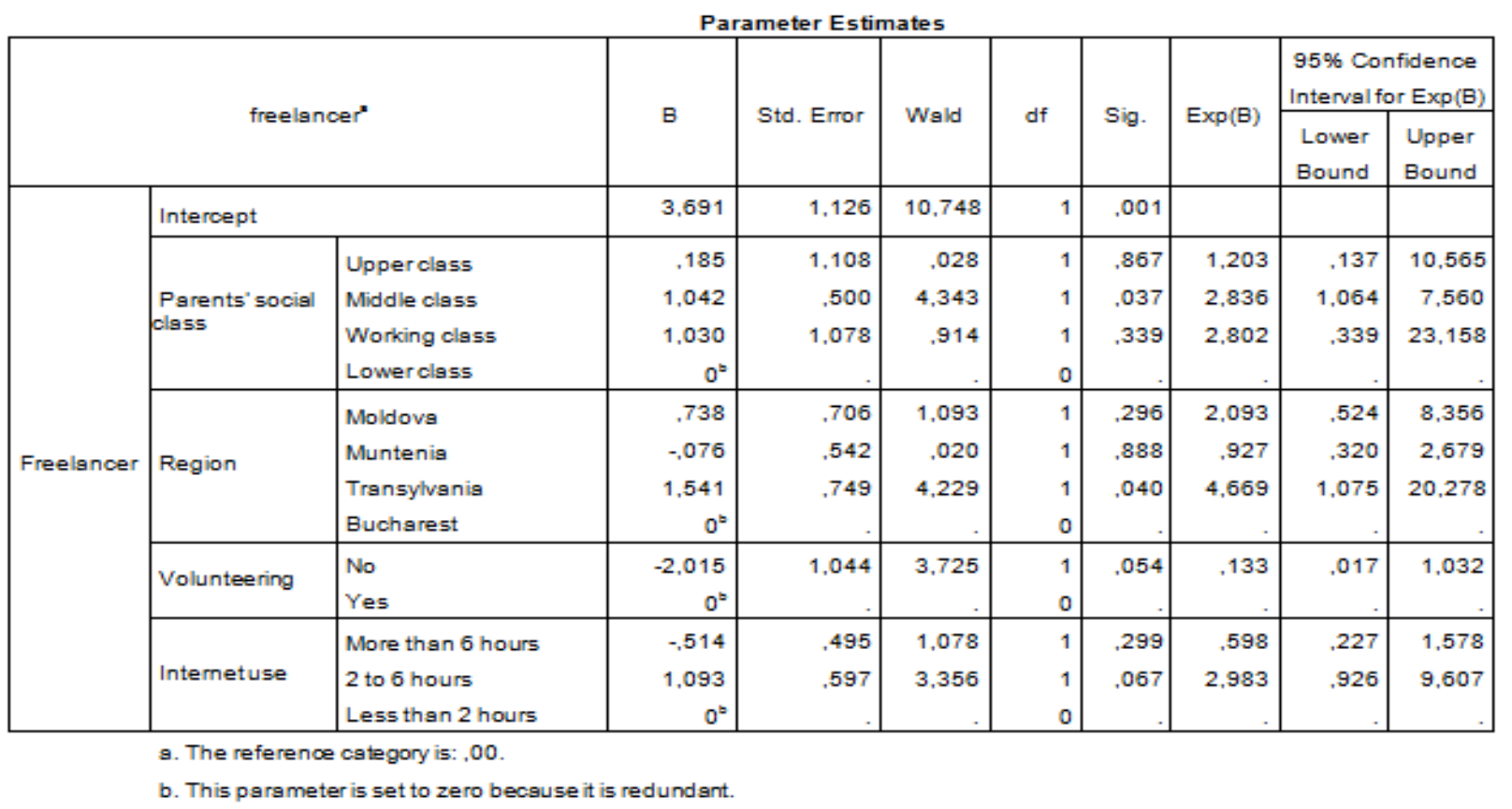

\section{Conclusions}

Young people entering the labour market are a vulnerable group, facing a higher risk of unemployment and an increased probability of working part-time or with fixed-term labour contract. Romania, as well as the European Union, faces the challenge of integrating young people into the labour market.

We saw that in Romania the youth unemployment rate in 2015 was close to the European average, but the percentage of long-term unemployed for young people was with 1.6 percentage points above the UE-28 average. Romania is the only EU country where the share of part-time employed 
young men was higher than that of women in 2015. The young Romanians work part-time mostly because they cannot find a full-time job, only $8 \%$ choosing this form of employment for educational reasons, compared to the majority of European youth who use part-time employment while still studying.

The econometric results of our study indicated that age, education, Internet use, volunteering activity and parents' social class are important factors in defining Romanian youth labour market success. The profile of the most likely to be unemployed young Romanian is the following: 15 to 19 years old; primary or lower secondary education graduate; Internet user for more than 2 hours a day; not involved in voluntary work; and coming from a lower class family. The young people with the highest chances of being part-time employed are those aged 1519 , with primary education (ISCED $0-2$ ), with a moderate use of the Internet (2- 6 hours), who are involved in volunteering activities and come from the historical region of Moldova. Regarding young freelancers in Romania, we found higher chances to carry on independent activities versus being employed for those living in Transylvania, engaged in voluntary activities, with a moderate use of the Internet, and coming from families with average income levels.

The existing problems on the youth labour market cannot be solved only by a single policy, but requires a mix of policies and initiatives that lead to the achievement of the European objectives. Young people deserve equal opportunities on the labour market, but this requires long-term investments. In its areas of competence, the EU and, therefore, the Member States must act through all policies available that can help improve the situation of young people.

Jobs are important, but they are not always sufficient to ensure full inclusion. Education and training can give young people the necessary skills to enter the labour market. Appropriately designed policies raising the educational levels of young people are likely to raise economic growth, and clearly do, at the individual level, increase the chances of finding work and the earnings of those in employment.

Most young people think the education system is inadequate and unsuited to the real dynamic needs of the labour market. The formal education programs are often too theoretical and that is why young people feel unprepared and without the necessary practical skills for the labour market. For this reason some young people delay to enter the labour market and prefer to continue their studies or look for low qualified jobs. Therefore there should be a better connection between the educational system and the labour market requirements. Sometimes young people turn to non-formal education as well, because it can complement formal education with distinct skills and it can also serve as an important resource for young people who do not have access to formal education. In addition, internships and volunteering can provide opportunities to develop life skills and improve employment prospects, including entrepreneurship.

Unemployment, especially among young people, is the greatest obstacle to the economic recovery in the European Union and one of the consequences of this is that a whole generation of young people is confused. The European Union needs a profound structural reform to become more competitive, and this cannot be done immediately. Thus, the essential reforms must be accompanied by measures with rapid effects aimed at stimulating the economic growth and supporting young people in finding a job and gaining essential skills. These measures will enhance confidence and will demonstrate to young people that they have a future. 


\section{References}

- Alexandru (Davidescu), A. A. (2014), 'Estimating the Size of Romanian Shadow Economy: A Labour Approach', Journal of Social and Economic Statistics, 3(3), 25-37

- Eurostat (2015), 'Being Young in Europe Today - Labour Market - Access and Participation', [Online], [Retrieved September 10, 2016] www.igfse.pt/upload/docs/2015/Eurostat_B eingYoung.pdf

- European Comission (2015), 'Labour Market and Wage Developments in Europe 2015' [Online], [Retrieved September 10, 2016], http://ec.europa.eu/social/BlobServlet?docI $\mathrm{d}=14290$ \&langId $=e n$

Bell, D.N.F, and Blanchflower, D. G., (2011a), 'Youth Unemployment in Europe and the United States', IZA Discussion Paper 5673

- Bell, D.N.F., and Blanchflower, D. G., (2011'b), 'Young People and the Great Recession', IZA Discussion Paper 5674

- Blanchflower, D.G., and Freeman, R., (2007), Youth Employment and Joblessness in Advanced Countries,University of Chicago Press.

- Borland, J., (1997), 'Unemployment in Australia - Prospects and Policies - an Overview', Australian Economic Review, 30 (4), 391-404

- Caliendo, M.; Künn, S., and Schmidl, R. (2011), 'Fighting Youth Unemployment: The Effects of Active Labor Market Policies', IZA Discussion Paper 6222.

- Carmeci, L., and Mauro, L. (2003), 'Long Run Growth and Investment in Education: Does Unemployment Matter?', Journal of Macroeconomics, 25, 123-137.

- Cartmel, F., and Furlong, A., (2000), 'Youth Unemployment in Rural Areas', Joseph
Rowntree Foundation, Work and Opportunity Series, 18

- Chapman, B.J., and Smith, P.N., (1992), 'The Probability of Leaving Unemployment: The Influence of Duration, Destination and Demographics', The Economic Record, 296309

- Escudero, V., and Mourelo, E.L., (2013), 'Understanding the Drivers of the Youth Labour Market in Kenya', ILO Research Paper 8

- Freedman, D.A., (2009), Statistical Models: Theory and Practice, Cambridge University Press, pp. 128.

- ILO, (2016), World Employment and Social Outlook 2016, Trends for Youth, International Labour Office, Geneva

- Joorabchi, T.N., Hassan, S. H., and Osman, N., (2013), 'Usage of the Internet and its Effect on Youth Development', [Online], [Retrieved September 10, 2016], http://www.scripps.ohiou.edu/wjmcr/vol45 /45.html

- Marks, G.N., and Fleming, N., (1998), 'Factors Influencing Youth Unemployment in Australia: 1980-1994', Longitudinal Surveys of Australian Youth, Research Report No 7, Australian Council for Educational Research

- O'Higgins, N, (2001), 'Youth Unemployment and Employment Policy: A Global Perspective', Munich Personal RePEc Archive (MPRA) Paper 23698.

- O'Higgins, N, (2015), 'Youth Unemployment', IZA Policy Paper 103

- Sandu, D., Stoica, C.A, Umbreș, R., and Friedrich-Ebert-Stiftung, (2016), 'Romanian Youth (2014)', GESIS Data Archive, Cologne. ZA5979 Data file Version 1.0.0, doi:10.4232/1.12324

- Verhaeghe, P., Li, Y., and Van de Putte, B. (2012), 'Socio-Economic and Ethnic 
Inequalities in Social Capital From the Family Among Labour Market Entrants', European Sociological Review, 1-12

- Wooden, M, (1996), 'The Youth Labour Market: Characteristics and Trends', Bulletin of Labour, 22(2), 137-160
- Zhang, J., Zhao, Z. (2011), 'Social-Family Network and Self-Employment: Evidence from Temporary Rural-Urban Migrants in China', IZA Discussion Paper 5446. 